\title{
A RESEARCH ON THE PRODUCTION OF GREEN COFFEE BEVERAGE FORTIFIED WITH APRICOT PULP
}

\author{
Canan Ece Tamer*
}

Bursa Uludag University Faculty of Agriculture Department of Food Engineering, 16059, Gorukle-Bursa, Turkey

Received / Geliş: 13.06.2018; Accepted /Kabul: 19.08.2018; Published online / Online bask1: 01.10.2018

Tamer, C.E. (2018). A research on the production of green coffee beverage fortified with apricot pulp. GIDA (2018) 43 (5): 800-811 doi: 10.15237/gida.GD18065

Tamer, C.E. (2018). Kayısı pulpu ile zenginleştirilmiş yeşil kahve içeceği üretimi üzerine bir araştırma. GIDA (2018) 43 (5): 800-811 doi: 10.15237/gida.GD18065

\begin{abstract}
The purpose of this research was to formulate a novel functional beverage possessing acceptable sensorial properties by using green coffee extract and apricot pulp. Green beans of C. arabica and C. caniphora were ground and brewed with drip filter coffee machines as 10 and $15 \%(\mathrm{w} / \mathrm{v})$ concentrations for $10 \mathrm{~min}$. Apricot pulp $(38 \%)$ and green coffee extracts $(62 \%)$, sucralose $(0.014 \mathrm{~g} / \mathrm{L})$ and lemon flavored emulsion $(0.15 \mathrm{~g} / \mathrm{L})$ were used in the formulation. Bioaccessible phenolics were determined between 3446.62 \pm 12.86 and $4042.08 \pm 71.26 \mathrm{mg}$ GAE $/ 100 \mathrm{~mL}$. Antioxidant activities of bioaccessible phenolics were ranged between $453 \pm 0.41-514 \pm 0.30 \mu \mathrm{mol}$ trolox $/ 100 \mathrm{~mL}$ and $729 \pm 0.03-794 \pm 0.04 \mu \mathrm{mol}$ trolox $/ 100 \mathrm{~mL}$ in $\mathrm{DPPH}$ and FRAP methods, respectively. Combination of green coffee extracts with apricot pulp allowed designing of functional cold beverage favored by consumers for their organoleptic features.
\end{abstract}

Keywords: Beverage, green coffee, apricot, antioxidant activity, bioaccessibility

\section{KAYISI PULPU İLE ZENGİNLEŞTİRİLMİŞ YEŞİL KAHVE İÇECEĞİ ÜRETİMİ ÜZERİNE BİR ARAŞTIRMA}

\section{ÖZ}

Bu çalışmanın amacı yeşil kahve ekstraktı ve kayısı pulpu kullanımı ile yeni, fonksiyonel ve kabul edilebilir duyusal özelliklere sahip bir içeceğin üretilmesidir. Coffea arabica and Coffea caniphora (Robusta) yeșil daneleri ögütülüp $\% 10$ ve $\% 15$ (w/v) konsantrasyonlarında 10 dakika süreyle damlamalı filtre kahve makinesinde suyla demlenmiştir. Formulasyonda, kahve ekstraktları $(\% 62)$, kayısı pulpu (\%38), sukraloz $(0.014 \mathrm{~g} / \mathrm{L})$ ve limon aromalı emulsiyon $(0.15 \mathrm{~g} / \mathrm{L})$ kullanılmıştır. İçecek örneklerinin biyoerişilebilir fenolik madde miktarı $3446.62 \pm 12.86$ ve $4042.08 \pm 71.26 \mathrm{mg}$ GAE/100mL arasında belirlenmiştir. Biyoerişilebilir fenoliklerin antioksidan aktiviteleri DPPH metoduna göre $453 \pm 0.41-514 \pm 0.30 \mu \mathrm{mol}$ troloks/100 mL, FRAP metoduna göre ise $729 \pm 0.03$ $794 \pm 0.04 \mu \mathrm{mol}$ troloks $/ 100 \mathrm{~mL}$ arasında değişmiştir. Yeşil kahve ekstraktlarının kayısı pulpu ile kombinasyonu, duyusal özellikleri bakımından tüketicilerin beğendiği fonksiyonel bir soğuk içeceğin oluşmasına olanak sağlamıştır.

Anahtar kelimeler: İçecek, yeşil kahve, kayısı, antioksidan aktivite, biyoerişilebilirlik

\footnotetext{
*Yazışmalardan sorumlu yazar / Corresponding author; 


\section{INTRODUCTION}

Coffee is one of the most commonly consumed beverage in the world. Unroasted mature or immature coffee beans are named green coffee. The total coffee produced in the world is from Coffea arabica (75\%) and Coffea caniphora (Robusta) (25\%) (Etienne, 2005; Belitz et al., 2009).

Green coffee contains poly and monosaccharides, proteins, free amino acids, lipids, fatty acids, sterols, polyphenols, phenolic acids, alkaloids, vitamins and minerals (Parras et al., 2007; Daglia et al., 2007; Köseoğlu Yılmaz et al., 2014). Caffeine in green coffee is a mild stimulant of the central nervous system (Bicho et al., 2013; Herman and Herman, 2013). Especially hydroxycinnamic acids (i.e. caffeic and ferulic acids), and their esters with quinic acid, named as chlorogenic acids (CHAs) are found in green coffee beans (Iwai et al., 2004; Sato et al., 2011; Budryn et al., 2013). CHAs prevent chronic disorders, cardiovascular and rheumatologic diseases with their antimutagenic and antiinflammatory effects (Cheng et al., 2007). The main contributors to the antioxidant capacity of green coffee are CHAs (Farah et al., 2006; Lima et al., 2010; Abrahao et al., 2010; Babova et al., 2016). Health benefits of coffee is mainly related with its phenolic composition, which is drastically reduced with roasting process (Perrone et al., 2002; Schenker et al., 2002; Somporn et al., 2011). During roasting, CHAs are particularly degraded, as well as antioxidant activity. Eventually, green coffee beans are accepted as better source of these components (Brezová et al., 2009; Köseoğlu Yilmaz et al., 2014; Wei and Tanokura, 2015; Şemen et al., 2017). For this reason, the consumption of green coffee products has shown increase in recent years as a healthier alternative to roasted coffee (Baeza et al., 2018).

The extensive scientific researches have been focused on examination of the relationship between coffee intake and chronic diseases and health outcomes (Pourshahidi et al., 2016). Despite the contradictive effects of caffeine and process induced toxicants of roasted coffee, utilization of green coffee in food industry as well as nutraceutical and pharmaceutical industry draws a great interest since green coffee is known as good resource of components having antioxidant and radical scavenging activities (Brezova et al., 2009; Anissi et al., 2014; Bresciani et al., 2014).

Health benefits and weight-loss properties of green coffee are under discussion. Recent researches allege that $\mathrm{CHAs}$ have antihypertensive effects (Zhao et al., 2012), prophylactic effects on Type II diabetes (Stefanello et al., 2014; Bassoli et al., 2008; Budryn et al. 2016) and lean towards to reduce visceral fat and body weight (Shimoda et al., 2006).

Balanced diet, physical activity and consumption of phytochemicals from various foods and beverages could provide a natural preventive approach to improve health status of individual, including potential efficient cancer prevention with minimal toxicity (Rossi et al., 2014). Nowadays, consumers demand ready to consume products related with health (Costa et al., 2012). Depending on its favorable composition and health-improving properties, utilization of green coffee as a supplement for functional foods has created interest. However, coffee's sensory and technological attributes could limit the use of coffee preparations for enrichment of foodstuffs (Budryn and Nebesny, 2013). Green coffee supplementation of food was the subject of several researches (Glei et al. 2006; Budryn and Nebesny, 2013; Dziki et al., 2015; Budryn et al., 2016; Vasudevaiah et al., 2017; S'wieca et al., 2017; Se ،czyk et al., 2017).

Apricot is a delicious and nutritious fruit. It is rich in minerals such as $\mathrm{K}$ and it contains considerable amounts of carotenoids (mainly $\beta$-carotene), and phenolics like chlorogenic, caffeic, p-coumaric and ferulic acids and $(+)$-catechin, (-)-epicatechin and rutin. As precursor of vitamin $A, \beta$-carotene is necessary for epithelia tissues covering body and organs, eye-health, osteogenesis, odontogenesis and working of endocrine glands. Apricot is considerable source of provitamin A carotenoids, as $250 \mathrm{~g}$ of fresh or $30 \mathrm{~g}$ of dried fruit supplies $100 \%$ of recommended dietary allowance (RDA) of carotenoids. $\beta$-carotene comprises 60 - 
$70 \%$ of total carotenoids in the fruit (DragovicUzelac et al., 2007; Hacıseferoğullar1 et al., 2007; Drogoudi et al., 2008).

The main reason of coffee consumption has been related to reducement of temporizing and defatigation, and for enhancing cognitive performance and its antioxidant capacity (Bicho et al., 2013; Herman and Herman, 2013). There is a progressing high interest in producing a "healthy and mild" coffee beverage (Clarke, 1987; Siebert et al., 2018). Because green coffee has a mild, green, bean-like aroma, the beverage containing only green coffee extract could not meet the consumers' expectations. For this reason, designing of novel low calorie functional beverage containing both green coffee extract and apricot pulp sweetened with sucralose was aimed in this research. Determination of extractable and bioaccessible phenolics, antioxidant activity and also evaluation of organoleptic characteristics of these beverages were the main goals of this research.

\section{MATERIAL and METHODS}

Green beans of Coffea arabica and Coffea caniphora (Robusta) were used after grinding by coffee grinder (Moulinex). Apricot pulp is obtained from Aroma Bursa Fruit Juices and Food Ind. Inc. Lemon flavored emulsion is supplied from AROMSA and sucralose (SPLENDA $\AA$ ) is purchased from local market. Depending on the result of the preliminary sensory evaluation, the most preferred ratios (\%) of green coffee extract and apricot pulp were $62 \%$ and $38 \%$ respectively. Sucralose $(0.014 \mathrm{~g} / \mathrm{L})$ was benefitted as zerocalorie sweetener and lemon flavored emulsion $(0.15 \mathrm{~g} / \mathrm{L})$ was added for flavor balance. Flow diagram of the beverage production is given in Figure 1.

\section{C. arabica / C. caniphora}

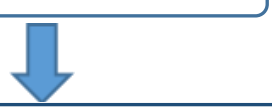

Brewing at two different concentrations ( $10 \%$ and $15 \% \mathrm{w} / \mathrm{v})$ of ground green coffee by drip filter coffee machine (Philips) for 10 minutes concentrations ( $10 \%$ and $15 \% \mathrm{w} / \mathrm{v}$ ) by filter coffee machine (Philips) for 10 minutes
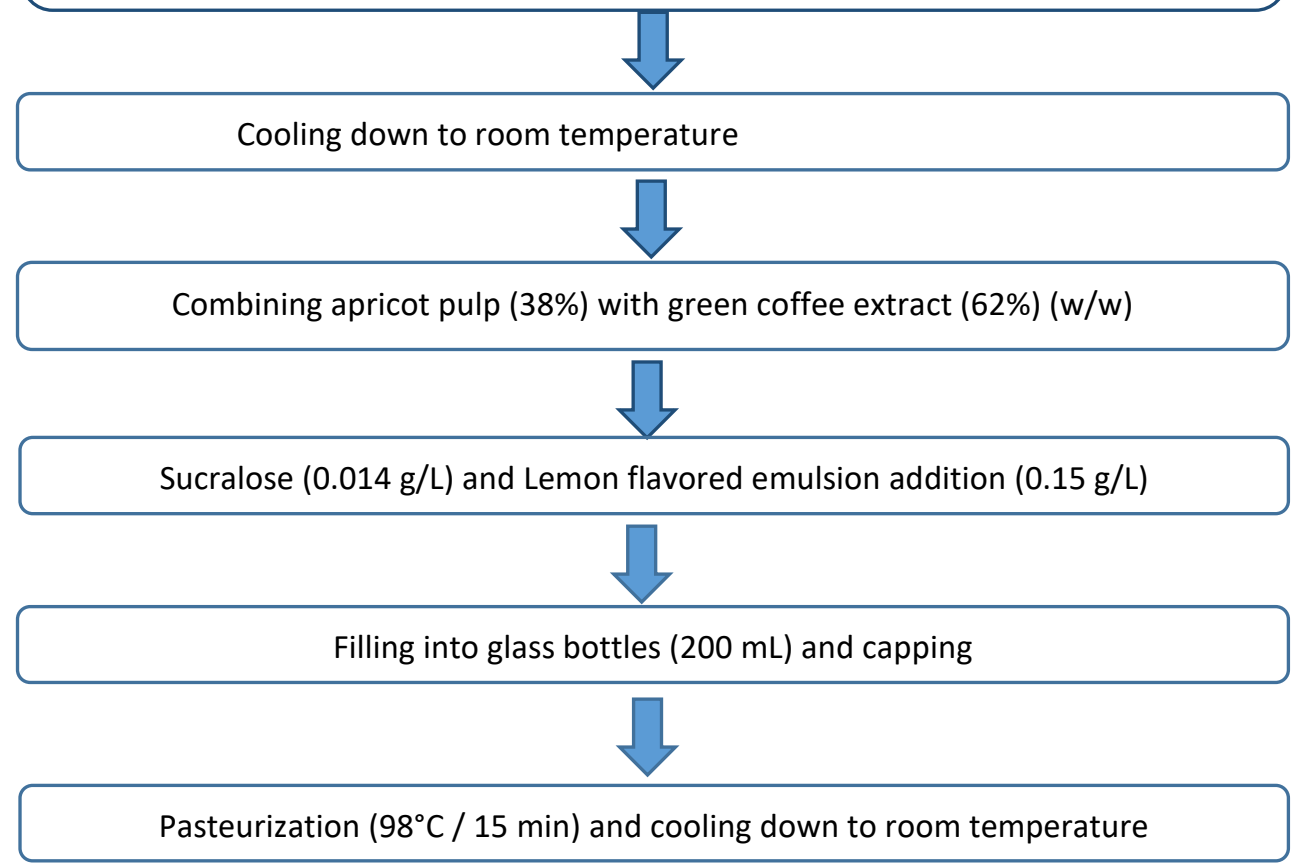

Figure 1. Flow diagram of the beverage production 


\begin{abstract}
ANALYSIS
Determination of some physicochemical properties of beverages

The water soluble dry matter $\left(b i^{\circ}\right)$ is measured by using RA-500 model KEM refractometer, total acidity is determined by potentiometric method, $\mathrm{pH}$ analysis were conducted by Mettler Toledo Sevencompact $\mathrm{pH} /$ Ion $\mathrm{pH}$ meter. Shimadzu (UV 1208) spectrophotometer was used for total phenolics and antioxidant activity analyses. Color analysis was done by Konica Minolta Chroma Meter, CR-5, Japan. All analyses were performed in three replicates.
\end{abstract}

\section{Extraction method of the samples}

The extracts of beverages were prepared according to modified method of Glahn et al. (1998). $2 \mathrm{~g}$ of sample was mixed with $20 \mathrm{~mL}$ of $\mathrm{HCl} /$ methanol/water solution $(1: 80: 10, \mathrm{v} / \mathrm{v})$ and put in a shaking water bath for $2 \mathrm{~h}$ at $20^{\circ} \mathrm{C}$ and then centrifuged (Sigma 3K 30, Germany) at 3500 $\mathrm{rpm}$ for $10 \mathrm{~min}$ at $20^{\circ} \mathrm{C}$. The supernatants were kept at $-20^{\circ} \mathrm{C}$ until analyzed.

\section{In Vitro Digestion Procedure}

For the determination of bioaccessibility of phenolics and antioxidants, in vitro digestion enzymatic extraction method that mimics the conditions of gastrointestinal tract (GIT) was applied with slight modifications (Glahn et al., 1998). $10 \mathrm{~mL}$ of distilled water and $0.5 \mathrm{~mL}$ of pepsin solution $(20 \mathrm{~g} / \mathrm{L}$ pepsin in $0.1 \mathrm{~mol} / \mathrm{L} \mathrm{HCl})$ were added to $1 \mathrm{~mL}$ of sample. By using $\mathrm{HCl}(5$ $\mathrm{mol} / \mathrm{L}), \mathrm{pH}$ was adjusted to 2 and then sample was incubated at $37^{\circ} \mathrm{C}$ in a shaking water bath for $1 \mathrm{~h}$. Simulation of gastric digestion was stopped by addition of $1 \mathrm{M} \mathrm{NaHCO}_{3}(\mathrm{pH}$ is adjusted to 7.2). $2.5 \mathrm{~mL}$ of bile/pancreatin solution $(2 \mathrm{~g} / \mathrm{L}$ of pancreatin and $12 \mathrm{~g} / \mathrm{L}$ of bile salt in $0.1 \mathrm{M}$ $\left.\mathrm{NaHCO}_{3}\right)$ and $2.5 \mathrm{~mL}$ of $\mathrm{NaCl} / \mathrm{KCl}$ solution $(120$ $\mathrm{mmol} / \mathrm{L} \mathrm{NaCl}$ and $5 \mathrm{mmol} / \mathrm{L} \mathrm{KCl}$ ) were added to the sample and simulation of intestinal digestion was conducted for the following $2 \mathrm{~h}$. Samples were centrifuged at $3500 \mathrm{rpm}$ for $10 \mathrm{~min}$ and the supernatant was used for determination of the bioaccesibility of total phenolics and their antioxidant activities.
Determination of total phenolic content

Folin-Ciocalteu method was applied to determine total phenolics (Spanos and Wrolstad, 1990). 0.25 $\mathrm{mL}$ of sample/extract, $2.3 \mathrm{~mL}$ of distilled water and $0.15 \mathrm{~mL}$ of Folin-Ciocalteu reagent (FC/Water, 1:5, v/v) were mixed within $10 \mathrm{~mL}$ volumetric flasks and vortexed (Velp Scientifica, Italia) for $15 \mathrm{~s}$ at room temperature. After $5 \mathrm{~min}$, $0.3 \mathrm{~mL}$ of $\mathrm{Na}_{2} \mathrm{CO}_{3}(35 \%)$ was added and mixed thoroughly. After incubation for $2 \mathrm{~h}$ at room temperature, absorbance of the mixture was measured at $725 \mathrm{~nm}$. Distilled water was used as the blank and gallic acid (GA) solution was used for the calibration of the standard curve $\left(\mathrm{R}^{2}=0.9835\right)$. Total phenolic content was given as gallic acid equivalents ( $\mathrm{mg}$ of GAE/100 mL sample).

\section{Determination of antioxidant activity}

Antioxidant activity of the samples were measured with DPPH and FRAP assays and the results were given as $\mu \mathrm{mol}$ trolox / $100 \mathrm{~mL}$.

\section{DPPH method of total antioxidant activity}

Antioxidant activity was determined by using modified method of the Katalinic et al. (2006). The assay involves the use of the free radical 2,2diphenyl-l-picrylhydrazyl (DPPH), proceed where antioxidants are allowed to react with the stable radical in methanol solution. $0.1 \mathrm{~mL}$ sample was added to $3.9 \mathrm{~mL}$ of $6 \times 10^{-5} \mathrm{M}$ methanol solution of DPPH radical and vortexed (Velp Scientifica, Italia) for 15-30 s. The reaction was proceeded in the dark condition at room temperature for 30 min, and then the absorbance was determined at $515 \mathrm{~nm}$. A trolox calibration curve $\left(\mathrm{R}^{2}=0.9929\right)$ was obtained by measuring the reduction in absorbance of the DPPH solution in the presence of different concentrations of trolox (10-200 $\mu \mathrm{mol} / \mathrm{L})$.

\section{FRAP method of total antioxidant activity}

$3 \mathrm{~mL}$ of FRAP reagent (incubated at $37^{\circ} \mathrm{C}$ ) was mixed with $300 \mu \mathrm{L}$ of distilled water and $100 \mu \mathrm{L}$ of the sample (or extraction solvent for the reagent blank) (Benzie and Strain, 1996). The samples and blank were incubated at $37^{\circ} \mathrm{C}$ for 30 min. Absorbance was measured immediately at $595 \mathrm{~nm}$ at the end of the incubation period. The 
FRAP reagent was prepared by mixing $25 \mathrm{~mL}$ of $0.3 \mathrm{~mol} / \mathrm{L}$ acetate buffer ( $\mathrm{pH} 3.6), 2.5 \mathrm{~mL}$ of 20 $\mathrm{mmol} / \mathrm{L} \mathrm{FeCl}_{3} \times 6 \mathrm{H}_{2} \mathrm{O}$ and $2.5 \mathrm{~mL} 10 \mathrm{mmol} / \mathrm{L}$ TPTZ solution in $40 \mathrm{mmol} / \mathrm{L} \mathrm{HCl}$. The concentration of sample in reaction mixture was $1.10^{-3} \mathrm{M}$ trolox $\left(\mathrm{R}^{2}=0.9993\right)$. The results were expressed as $\mu \mathrm{mol}$ trolox $/ 100 \mathrm{~mL}$ sample.

\section{Sensory Analysis}

Sensory analysis was done by a selected panel comprising 9 judges from academicians and graduate students. The beverages $\left(15^{\circ} \mathrm{C}\right)$ were coded by three-digit random numbers and served to the panelists randomly. Samples were evaluated for color, appearance, odor and taste by using a hedonic scale. For this aim, a 9-point hedonic scale with 9-like extremely, 8-like very much, 7like moderately, 6-like slightly, 5- neither like or dislike, 4-dislike slightly, 3-dislike moderately, 2- dislike very much, and 1-dislike extremely was applied. Water was used to clear the palate before the each test sample (Altuğ and Elmac1, 2011).

\section{Statistical Analysis}

The experiment was conducted in a completely randomized design with three replications. The results were statistically evaluated by ANOVA using the JMP 6.0 (SAS Institute Inc. NC, 27513). When significant differences were determined $(\mathrm{p}$ $<0.05$ ), the Least Significant Difference (LSD) test was used to define the differences among means.

\section{RESULTS and DISCUSSION}

The results of the physicochemical analysis of the beverages were shown in Table 1.

Table 1. Physicochemical analysis results of the of beverages (mean \pm standard deviation)

\begin{tabular}{|c|c|c|c|c|c|c|}
\hline \multirow[b]{2}{*}{$\begin{array}{l}\text { Beverage } \\
\text { Samples }\end{array}$} & \multirow{2}{*}{$\begin{array}{l}\text { Water } \\
\text { soluble dry } \\
\text { matter } \\
\left(\mathrm{brrix}^{\circ}\right) \\
(\mathrm{g} / 100 \mathrm{~g})\end{array}$} & \multirow{2}{*}{$\begin{array}{l}\text { Total } \\
\text { acidity* } \\
\text { (g/100 } \\
\text { mL) }\end{array}$} & \multirow[b]{2}{*}{$\mathrm{pH}$} & \multicolumn{2}{|c|}{ Total phenolics } & \multirow[b]{2}{*}{$\begin{array}{c}\text { Total phenolics } \\
\text { bioaccessibility** } \\
\text { (\%) }\end{array}$} \\
\hline & & & & $\begin{array}{c}\text { Extractable } \\
\text { phenolics } \\
(\mathrm{mg} \text { GAE } / 100 \\
\mathrm{mL})\end{array}$ & $\begin{array}{c}\text { Bioaccessible } \\
\text { phenolics } \\
\text { (mg GAE } / 100 \\
\mathrm{~mL})\end{array}$ & \\
\hline$\overline{\mathrm{A}}$ & $4.70 \pm 0.10^{c}$ & $0.64 \pm 0.00^{\mathrm{n}}$ & $3.79 \pm 0.04^{\mathrm{bc}}$ & $2419.13 \pm 183.04^{n}$ & $3446.62 \pm 12.86^{c}$ & $142.47 \pm 9.96^{\mathrm{b}}$ \\
\hline $\mathrm{B}$ & $4.60 \pm 0.00^{c}$ & $0.65 \pm 0.02^{\mathrm{n}}$ & $3.77 \pm 0.04^{c}$ & $2498.15 \pm 135.76^{n}$ & $3698.86 \pm 49.58^{\mathrm{b}}$ & $148.06 \pm 8.43^{\mathrm{b}}$ \\
\hline $\mathrm{C}$ & $5.17 \pm 0.06^{\mathrm{a}}$ & $0.66 \pm 0.02^{\mathrm{n}}$ & $3.86 \pm 0.04^{a}$ & $2476.90 \pm 25.56^{\mathrm{n}}$ & $3700.05 \pm 80.86^{\mathrm{b}}$ & $149.38 \pm 4.39^{\mathrm{b}}$ \\
\hline $\mathrm{D}$ & $5.03 \pm 0.06^{\mathrm{b}}$ & $0.65 \pm 0.01^{\mathrm{n}}$ & $3.84 \pm 0.04^{\mathrm{ab}}$ & $2405.97 \pm 11.93^{\mathrm{n}}$ & $4042.08 \pm 71.26^{a}$ & $168.00 \pm 2.41^{a}$ \\
\hline
\end{tabular}

A: beverage containing C. robusta extract $(10 \% \mathrm{w} / \mathrm{v})$

B: beverage containing $C$. arabica extract $(10 \% \mathrm{w} / \mathrm{v})$

C: beverage containing $C$. robusta extract $(15 \% \mathrm{w} / \mathrm{v})$

D: beverage containing $C$. arabica extract $(15 \% \mathrm{w} / \mathrm{v})$

a, b, c, d Letters indicate significant differences among beverages, $P<0.05$.

$\mathrm{n}$ indicates statistically insignificant results among beverages, $P>0.05$.

$*$ as citric acid

** Total phenolics bioaccessibility was calculated as (Bioaccessible phenolics / Extractable phenolics) x 100

The water soluble dry matter $\left(b^{\circ} x^{\circ}\right)$ of the beverages were found to vary between $4.60 \pm 0.00$ $5.17 \pm 0.06 \mathrm{~g} / 100 \mathrm{~g}$. As it was expected, when coffee extract ratio was increased, brix $^{\circ}$ was also increased. While the differences between brix ${ }^{\circ}$ and $\mathrm{pH}$ value of the samples were statistically significant $(P<0.05)$, the differences between total acidity of the samples were found insignificant $(P>0.05)$. "The sample C" containing C. robusta $(15 \%, \mathrm{w} / \mathrm{v})$ had the highest brix $^{\circ}(5.17 \pm 0.06 \mathrm{~g} / 100 \mathrm{~g})$, total acidity $(0.66 \pm 0.02$ $\mathrm{g} / 100 \mathrm{~mL}$ ) and $\mathrm{pH}$ value $(3.86 \pm 0.04)$.

Jeszka-Skowron et al. (2016) reported that $\mathrm{pH}$ was changed in $\mathrm{pH}$ of green coffee extracts of Robusta type as 4.29-5.03 and in Arabica type as 4.60-4.92. Because of the use of apricot pulp in the formulation, our $\mathrm{pH}$ results was lower than the abovementioned $\mathrm{pH}$ values of green coffee extract. Addition of apricot pulp contributed flavor improvement of the beverages as well as 
reduced the $\mathrm{pH}$. By this means, beverages could be preserved easily with pasteurization.

Extractable phenolic content of the beverages was not statistically significant $(P>0.05)$, while the highest value of the bioaccessible phenolics (4042.08 $771.26 \mathrm{mg}$ GAE/100 mL) was determined in "the sample D". These results were similar to findings reported by Jeszka-Skowron et al. (2017). Total phenolics of green coffe beans was measured as $46.49 \pm 0.78-68.01 \pm 0.27$ and $14.17 \pm 0.52-17.37 \pm 1.96 \mathrm{mg}$ GAE/g for Robusta and Arabica respectively in their study.

Polyphenols must first survive the passage though the gastrointestinal tract (GIT), before exerting any physiological effect (Bouayed et al., 2012). Absorption and metabolism of them are determined principally by their physico-chemical properties. Their structure, molecular size, polymerization or glycosylation degree, solubility, and conjugation with other phenolics are critical factors. In addition to this, food composition, release of phenolics from the food matrix, interactions with other components and the presence of suppressors or cofactors affect bioaccessibility of polyphenols (Parada and Aguilera, 2007). Small-molecular weight phenolic acids like gallic acid, flavones, catechins, quercetin glucosides and isoflavones are easily absorbed through the GIT (Martin and Apple, 2010). Contrarily, higher molecular weight polyphenols like proanthocyanidins are poorly absorbed. Before being absorbed, most proanthocyanidins have to be degraded into monomer or dimer units (Hackman et al., 2008). In vitro digestion procedures have been commonly used and offer an alternative tool to estimate the bioaccessibility of polyphenols depending on their simplicity and speed (Spínola et al., 2018; Carbonell-Capella et al., 2014).

Total phenolics bioaccessibility of the beverage samples changed between $142.47 \pm 9.96 \%-168.00$ $\pm 2.41 \%$. Previous researches reported in vitro increase of total phenolic and flavonoid contents upon simulated digestion which is in agreement with our results (Chen et al., 2015; Podsędek et al., 2014; Tagliazucchi et al., 2010). It was reported that, when non-extractable phenolics are released from the food matrix by the help of digestive enzymes in the small intestine and bacterial degradation in the large intestine, they may become bioactive in gut (Jenner et al., 2005). Besides, while dietary fiber, divalent elements, and high in protein and viscous meals are likely to induce impairing effects on polyphenol bioaccessibility; digestible carbohydrates, dietary lipids (especially for hydrophobic polyphenols), and additional antioxidants may improve polyphenol bioavailability (Bohn, 2014). It has been found that antioxidants and phenolics in certain fruit and vegetable juices became more bioaccessible post digestion (Ryan and Prescott. 2010, Wootton-Beard et al., 2011). Phenolic compounds from fruit juices are expected to be more bioaccessible and bioavailable than those from fruit flesh because of their differences in proximate fiber content. Kris-Etherton et al. (2002) determined that the bioavailability and antioxidant capacity of the phenolic compounds are preserved, or may increase, when the mango is processed into juice. Fawole et al. (2015) investigated the effect of digestion on total phenolic concentration and antioxidant capacity of pomegranate juice and by-products. Total phenolic compounds and total antioxidant capacity after the duodenal phase of in vitro digestion were higher than the initial values (before digestion), suggesting the effect the environments of in vitro digestion on total phenolics in pomegranate fruit fractions. In contrast, after the duodenal phase, total phenolic compounds decreased significantly compared to gastric phase. Tomas et al. (2018) reported that with an increase in dietary fiber content, there is a concomitant decrease in the in vitro bioaccessibility of antioxidants. 
Table 2. Results of the antioxidant activity analysis of beverages (mean \pm standard deviation)

\begin{tabular}{|c|c|c|c|c|c|c|}
\hline \multirow[b]{2}{*}{$\begin{array}{l}\text { Beverage } \\
\text { samples }\end{array}$} & \multicolumn{6}{|c|}{ Antioxidant activity } \\
\hline & $\begin{array}{c}\text { DPPH } \\
\text { Chemical } \\
\text { extract } \\
\text { ( } \mu \text { mol } \\
\text { trolox/ } \\
100 \mathrm{~mL})\end{array}$ & $\begin{array}{c}\text { DPPH } \\
\text { Physiological } \\
\text { extract } \\
\text { ( } \mu \text { mol trolox/ } \\
100 \mathrm{~mL})\end{array}$ & $\begin{array}{c}\text { DPPH } \\
\text { Bioaccessibility* } \\
(\%)\end{array}$ & $\begin{array}{l}\text { FRAP } \\
\text { Chemical } \\
\text { extract } \\
\text { ( } \mu \mathrm{mol} \\
\text { trolox/ } \\
100 \mathrm{~mL})\end{array}$ & $\begin{array}{c}\text { FRAP } \\
\text { Physiological } \\
\text { extract } \\
\text { ( } \mu \mathrm{mol} \\
\text { trolox/ } \\
100 \mathrm{~mL})\end{array}$ & $\begin{array}{c}\text { FRAP } \\
\text { Bioaccessibility* } \\
(\%)\end{array}$ \\
\hline $\mathrm{A}$ & $848 \pm 0.02^{n}$ & $473 \pm 0.25^{\mathrm{ab}}$ & $55.77 \pm 2.95^{\mathrm{ab}}$ & $938 \pm 0.03^{\mathrm{d}}$ & $745 \pm 0.04^{b}$ & $79.42 \pm 0.54^{a}$ \\
\hline $\mathrm{B}$ & $845 \pm 0.04^{\mathrm{n}}$ & $514 \pm 0.30^{\mathrm{a}}$ & $60.83 \pm 3.86^{\mathrm{a}}$ & $1066 \pm 0.03^{c}$ & $729 \pm 0.03^{c}$ & $68.38 \pm 0.34^{b}$ \\
\hline $\mathrm{C}$ & $846 \pm 0.04^{\mathrm{n}}$ & $453 \pm 0.41^{b}$ & $53.55 \pm 5.10^{\mathrm{b}}$ & $1190 \pm 0.04^{a}$ & $752 \pm 0.10^{\mathrm{b}}$ & $63.19 \pm 0.85^{c}$ \\
\hline $\mathrm{D}$ & $843 \pm 0.08^{n}$ & $513 \pm 0.11^{a}$ & $60.85 \pm 1.31^{\mathrm{a}}$ & $1151 \pm 0.03^{b}$ & $794 \pm 0.04^{a}$ & $68.98 \pm 0.46^{\mathrm{b}}$ \\
\hline
\end{tabular}

A: beverage containing C. robusta extract $(10 \% \mathrm{w} / \mathrm{v})$

B: beverage containing $C$. arabica extract $(10 \% \mathrm{w} / \mathrm{v})$

C: beverage containing $C$. robusta extract $(15 \% \mathrm{w} / \mathrm{v})$

D: beverage containing $C$. arabica extract $(15 \% \mathrm{w} / \mathrm{v})$

a, b, c, d Letters indicate significant differences among beverages, $P<0.05$.

$\mathrm{n}$ indicate statistically insignificant results among beverages, $P>0.05$.

*Bioaccessibility of antioxidant activity was calculated as (antioxidant activity of physiological extract/ antioxidant activity of chemical extract) x 100

Since each individual assay demonstrates antioxidant capacity in a different way, more than one assay should be used to measure the antioxidant activity of foods. For this reason, application of at least two assays based on different reaction mechanisms leads to better projection of the antioxidant activity of a sample (Pekal et al., 2012). Consequently, antioxidant activities of these phenolics were determined spectrophotometrically with DPPH and FRAP methods. As given in Table 2, although DPPH antioxidant activity of extractable phenolics was determined statistically insignificant $(P>0.05)$, antioxidant activities of bioaccessible phenolics were changed significantly $(P<0.05)$. The free radical scavenging capacity of the beverages measured by the DPPH method and the reducing power determined by the FRAP method showed that the antioxidant activity of physiological extract of the beverages was related to their bioaccessible phenolic content. The highest antioxidant activity of bioaccessible phenolics determined with DDPH assay was found in "the sample D" (513 $\pm 0.11 \mu \mathrm{mol}$ trolox $/ 100 \mathrm{~mL})$ and "the sample B" (514 $\pm 0.30 \mu \mathrm{mol}$ trolox $/ 100 \mathrm{~mL})$ which were prepared from C. arabica extract. Also, "the sample D" demonstrated the highest antioxidant activity of bioaccessible phenolics
(794 $\pm 0.04 \mu \mathrm{mol}$ trolox $/ 100 \mathrm{~mL}$ ) determined with FRAP assay.

Jeszka-Skowron et al. (2017) measured antioxidant capacity of Robusta and Arabica type green coffee extact as $32.14 \pm 2.62-46.23 \pm 0.54$ (mmol trolox/100 g) and $16.13 \pm 2.57-23.41 \pm$ 1.81 (mmol trolox/100 g) in DPPH assay respectively.

Bioaccessibility of antioxidant activity of the beverages was changed between $53.55 \pm 5.10 \%$ $60.85 \pm 1.31 \%$ for DPPH assay and $63.19 \pm 0.85$ $\%-79.42 \pm 0.54 \%$ for FRAP assay.

The color of green coffee beans can be affected by a number of factors during cultivation, picking, drying, and milling. Color specifications of beverages were noticed in Table 3. All color parameters were measured significantly different $(p<0.05)$. Except a* (redness) value, "the sample C" had the highest $L^{*}$ (brightness), and $b^{*}$ (yellowness), chroma and hue values. Beverages (sample A and sample C) prepared with C. robusta extract had higher L*, $b^{*}$, chroma and hue values than others produced with $C$. arabica. Akdemir Evrendilek et al. (2013) determined color parameters of the apricot nectar samples as 34.98, 11.76, and 36.12 for $\mathrm{L}^{*}, \mathrm{a}^{*}$, and $\mathrm{b}^{*}$ values, respectively. While $L^{*}$ value of the apricot nectar 
was similar to green coffee beverages fortified with apricot pulp; $a$ and $b$ values were lower. This was related to the difference in beverage formulation containing green coffee extract.

Table 3. Color values of beverages (mean \pm standard deviation)

\begin{tabular}{|l|c|c|c|c|c|}
\hline Beverage samples & $\mathrm{L}^{*}$ & $\mathrm{a}^{*}$ & $\mathrm{~b}^{*}$ & Chroma $\left(\mathrm{C}^{*}\right)$ & Hue \\
\hline A & $34.10 \pm 0.04^{\mathrm{b}}$ & $22.14 \pm 0.01^{\mathrm{b}}$ & $54.71 \pm 0.07^{\mathrm{b}}$ & $58.99 \pm 0.02^{\mathrm{b}}$ & $67.97 \pm 0.03^{\mathrm{b}}$ \\
\hline B & $31.88 \pm 0.02^{\mathrm{d}}$ & $22.77 \pm 0.02^{\mathrm{a}}$ & $52.25 \pm 0.11^{\mathrm{d}}$ & $56.99 \pm 0.10^{\mathrm{d}}$ & $66.45 \pm 0.03^{\mathrm{d}}$ \\
\hline C & $35.61 \pm 0.05^{\mathrm{a}}$ & $21.45 \pm 0.01^{\mathrm{c}}$ & $55.78 \pm 0.06^{\mathrm{a}}$ & $59.76 \pm 0.06^{\mathrm{a}}$ & $68.97 \pm 0.02^{\mathrm{a}}$ \\
\hline D & $32.70 \pm 0.01^{\mathrm{c}}$ & $22.78 \pm 0.01^{\mathrm{a}}$ & $53.64 \pm 0.06^{\mathrm{c}}$ & $58.28 \pm 0.06^{\mathrm{c}}$ & $66.98 \pm 0.02^{\mathrm{c}}$ \\
\hline
\end{tabular}

A: beverage containing C. robusta extract $(10 \% \mathrm{w} / \mathrm{v})$

B: beverage containing C. arabica extract $(10 \% \mathrm{w} / \mathrm{v})$

C: beverage containing C. robusta extract $(15 \% \mathrm{w} / \mathrm{v})$

D: beverage containing C. arabica extract $(15 \% \mathrm{w} / \mathrm{v})$

a, b, c, d Letters indicate significant differences among beverages, $P<0.05$.

Sensory analysis results were given in Table 4.

Table 4. Sensory analysis results of the of beverages* (mean \pm standard deviation)

\begin{tabular}{|l|c|c|c|c|}
\hline Beverage samples & Color & Odor & Appearance & Taste \\
\hline A & $7.78 \pm 0.97$ & $7.44 \pm 0.73$ & $6.56 \pm 1.33$ & $5.89 \pm 2.42$ \\
\hline B & $7.78 \pm 0.97$ & $7.44 \pm 0.73$ & $6.56 \pm 1.33$ & $6.89 \pm 1.62$ \\
\hline C & $7.56 \pm 1.13$ & $7.44 \pm 0.73$ & $6.44 \pm 1.59$ & $5.44 \pm 2.46$ \\
\hline D & $7.44 \pm 1.33$ & $7.44 \pm 0.73$ & $5.78 \pm 1.99$ & $4.78 \pm 2.39$ \\
\hline
\end{tabular}

A: beverage containing C. robusta extract $(10 \% \mathrm{w} / \mathrm{v})$

B: beverage containing C. arabica extract $(10 \% \mathrm{w} / \mathrm{v})$

C: beverage containing C. robusta extract $(15 \% \mathrm{w} / \mathrm{v})$

D: beverage containing C. arabica extract $(15 \% \mathrm{w} / \mathrm{v})$

*Results were statistically insignificant among beverages, $(P>0.05)$.

All of the panelists reported their positive opinions about beverage samples. There was no statistically significant difference between tested criteria among beverages $(P>0.05)$. However, when the green coffee concentration increased, color, appearance and taste scores were reduced.

\section{CONCLUSION}

Finding possibility of green coffee extract utilization may help to design novel functional apricot beverage. The sensory evaluation results indicated that beverage formulations was given satisfactory overall acceptability. However, increment of the green coffee extract concentration resulted in reduction of appearance and taste scores especially. While "the sample B" containing C. arabica extract $(10 \% \mathrm{w} / \mathrm{v})$ was the most preferred beverage for sensory criteria, "the sample D" containing C. arabica extract $(15 \%$ $\mathrm{w} / \mathrm{v}$ ) was the least preferred one. The highest total phenolics bioaccessibility and DPPH bioaccessibility were determined in "the beverage D" containing C. arabica extract $(15 \% \mathrm{w} / \mathrm{v})$.
However, "the beverage A" containing C. robusta extract $(10 \% \mathrm{w} / \mathrm{v})$ demonstrated the highest FRAP bioaccessibility.

\section{REFERENCES}

Abrahao, S.A., Pereira, R., Duarte, S.M.D., Lima, A.R., Alvarenga, D.J., Ferreira, E.B. (2010). Coffee (Coffea arabica L.) bioactive compounds and antioxidant activity. Cienc Agrotecnol, 34: 414420.

Akdemir Evrendilek, G., Altuntas, J., Sangun, M.K., Zhang, H.Q. (2013) Apricot nectar processing by pulsed electric fields. International Journal of Food Properties, 16:1, 216-227,

Altuğ, T., Elmaci, Y. (2011). Gidalarda duyusal değerlendirme. 2. Baskı. Sidas Medya, İzmir, Türkiye, 134 s. ISBN: 978994-456-60-87.

Anissi, J., El Hassouni, M., Ouardaoui, A., Sendide, K. (2014). A comparative study of the antioxidant scavenging activity of green tea, black tea and coffee extracts: a kinetic approach. Food Chem, 150: 438-447. 
Babova, O., Occhipinti, A., Maffei, M.E. (2016). Chemical partitioning and antioxidant capacity of green coffee (Coffea arabica and Coffea canephora) of different geographical origin. Phytochemistry, 123: 33-39.

Baeza, G., Sarriá, B., Bravo, L. and Mateo, R. (2018). Polyphenol content, in vitro bioaccessibility and antioxidant capacity of widely consumed beverages. J Sci Food Agric, 98: 13971406.

Bassoli, B.K., Cassolla, P., Borba-Murad, G.R., Constantin, J., Salgueiro-Pagadigorria, C.L., Bazotte, R.B., da Silva R.S., de Souza H.M. (2008). Chlorogenic acid reduces the plasma glucose peak in the oral glucose tolerance test: Effects on hepatic glucose release and glycaemia. Cell Biochem Funct, 26: 320-328.

Belitz, H.D., Grosch, W., Schieberle, P. (2009). Coffee, tea, cocoa. In: Food Chemistry, Belitz, H.D., Grosch, W., Schieberle, P. (Eds.), fourth ed. Springer, Leipzig, pp. 938-951.

Benzie I.F.F., Strain J.J. (1996). The ferric reducing ability of plasma (FRAP) as a measure of "antioxidant power": The FRAP assay. Anal Biochem, 76: 70-76.

Bohn, T. (2014). Dietary factors affecting polyphenol bioavailability. Nutr Rev, 72(7): 42952.

Bouayed, J., Deußer, H., Hoffmann, L., Bohn, T. (2012). Bioaccessible and dialysable polyphenols in selected apple varieties following in vitro digestion vs. their native patterns. Food Chem, 131(4): 1466-1472.

Bresciani, L., Calani, L., Bruni, R., Brighenti, F., Del Rio, D. (2014). Phenolic composition, caffeine content and antioxidant capacity of coffee silverskin. Food Res Int, 61: 196-201.

Brezova, V., Slebodova, A., Stasko, A. (2009). Coffee as a source of antioxidants: an EPR study. Food Chem, 114: 859-868.

Budryn, G., Zyzelewicz, D., Nebesny, E., Oracz, J., Krysiak, W. (2013). Influence of addition of green tea and green coffee extracts on the properties of fine yeast pastry fried products. Food Res Int, 50: 149-160.
Budryn, G., Nebesny, E. (2013). Effect of green and roasted coffee antioxidants on quality and shelf life of cookies and chocolates. J Food Process Preserv, 37: 835-845.

Budryn, G., Zaczynska, D., Oracz, J. (2016). Effect of addition of green coffee extract and nanoencapsulated chlorogenic acids on aroma of different food products. LWT - Food Sci Technol, 73:197-204.

Carbonell-Capella, J. M., Buniowska, M., Barba, F. J., Esteve, M. J., Frígola, A. (2014). Analytical methods for determining bioavailability and bioaccessibility of bioactive compounds from fruits and vegetables: A review. Compr Rev Food Sci Food Saf, 13(2): 155-171.

Chen, G.L., Chen, S.G., Xie, Y.Q., Chen, F., Zhao, Y.Y., Luo, C.X., Gao, Y.Q. (2015). Total phenolic, flavonoid and antioxidant activity of 23 edible flowers subjected to in vitro digestion. $J$ Funct Foods, 17: 243-259.

Cheng, J.C., Dai, F., Zhou, B., Yang, L., Liu, Z.L. (2007). Antioxidant activity of hydroxycinnamic acid derivatives in human low density lipoprotein: Mechanism and structure-activity relationship. Food Chem, 104: 132-139.

Clarke, R. J. (1987). Grading, storage, pretreatments and blending. In: Coffee, Clarke, R.J., Macrae, R. (eds.), Volume 2, Springer, Netherlands, pp. 35-58.

Costa, A.S.G., Nunes, M.A., Almeida, I.M.C., Carvalho, M.R., Barroso, M.F., Alves, R.C., Oliveira, M.B.P.P. (2012). Teas, dietary supplements and fruit juices: A comparative study regarding antioxidant activity and bioactive compounds. LWT - Food Sci Technol, 49: 324-328.

Daglia, M., Papetti, A., Gregotti, C., Berte, F., Gazzani, G. (2007). In vitro antioxidant and ex vivo protective activities of green and roasted coffee. J Agric Food Chem, 48: 1449-1454.

Dragovic-Uzelac, V., Levaj, B., Mrkic, V., Bursac, D., Marija Boras, M. (2007). The content of polyphenols and carotenoids in three apricot cultivars depending on stage of maturity and geographical región. Food Chem, 102: 966975.Drogoudi, P.D., Vemmos, S., Pantelidis, G., 
Petri, E., Tzoutzoukou, C., Karayiannis, I. (2008). Physical characters and antioxidant, sugar, and mineral nutrient contents in fruit from 29 apricot (Prunus armeniaca L.) cultivars and hybrids. J Agric Food Chem, 56(22): 10754-10760.

Dziki, D., Gawlik-Dziki, U., Krzykowski, A. (2015). Ground green coffee beans as a functional food supplement - Preliminary study. LWT Food Sci Technol, 63(1): 691-699.

Etienne, H. (2005). Somatic embryogenesis protocol: coffee (Coffea arabica L. and C. canephora P.). In: Protocol for Somatic Embryogenesis in Woody Plant, Jain, S.M., Gupta, P.K. (eds.), Springer, Dordrecht, pp. 167-168.

Farah, A., De Paulis, T., Moreira, D.P., Trugo, L.C., Martin, P.R. (2006). Chlorogenic acids and lactones in regular and water-decaffeinated arabica coffees. J Agric Food Chem, 54: 374-381.

Fawole, O.A., Opara, U.L., Chen, L. 2015. Bioaccessibility of total phenolic concentration and antioxidant capacity of pomegranate fruit juice and marc after in vitro digestion. Proc. $5^{\text {th }}$ International Conference Postharvest Unlimited, Eds.: Manganaris et al. Acta Hort, 1079, 285-290.

Glahn, R.P., Lee, O.A., Yeung, A., Goldman, M.I., Miller, D.D. (1998). Caco-2 cell ferritin formation predicts nonradiolabeled food iron availability in an in vitro digestion/Caco-2 cell culture model. J Nutrition, 128: 1555-1561.

Glei, M., Kirmse, A., Habermann, N., Persin, C., Pool-Zobel, B.L. (2006). Bread enriched with green coffee extract has chemoprotective and antigenotoxic activities in human cells. Nutr Cancer, 56: 182-192.

Hacıseferoğulları, H., Gezer, I., Özcan, M.M., Asma, B.M. (2007). Postharvest chemical and physical-mechanical properties of some apricot varieties cultivated in Turkey. J Food Eng, 79: 364373.

Hackman, R.M., Polagruto, J.A., Yan Zhu, Q., Sun, B., Fujii, H., Keen, C.L. (2008). Flavanols: digestion, absorption and bioactivity. Phytochem Rev, 7:195-208.
Herman, A., Herman, A.P. (2013). Caffeine's mechanisms of action and its cosmetic use. Skin Pharmacol Physiol, 26: 8-14.

Iwai, K., Kishimoto, N., Kakino, Y., Mochida, K., Fujita, T. (2004). In vitro antioxidative effects and tyrosinase inhibitory activities of seven hydroxycinnamoyl derivatives in green coffee beans. J Agric Food Chem, 52: 4893-4898.

Jenner, A. M., Rafter, J., Halliwell, B. (2005). Human fecal water content of phenolics: The extent of colonic exposure to aromatic compounds. Free Radic Biol Med, 38: 763-772.

Jeszka-Skowron, M., Stanisz, E., De Pena, M.P. (2016). Relationship between antioxidant capacity, chlorogenic acids and elemental composition of green coffee. LWT - Food Sci Technol, 73: 243-250.

Jeszka-Skowron, M., Zgoła-Grzeskowiak, A., Waskiewicz, A., Stepien L., Stanisz, E. (2017). Positive and negative aspects of green coffee consumption - antioxidant activity versus mycotoxins. J Sci Food Agric, 97: 4022-4028.

Katalinic, V., Milos, M., Kulisic, T., Jukic, M. (2006). Screening of 70 medicinal plant extracts for antioxidant capacity and total phenols. Food Chem, 94(4): 550-557.

Köseoğlu Yılmaz, P., Hacıbekiroğlu, I., Kolak, U. (2014). Effect of roasting on antioxidant and anticholinesterase capacities of coffee. J Food Nutr Res, 53(3): 232-239.

Kris-Etherton, P.M.; Hecker, K.D.; Bonanome, A.; Coval, S.M.; Binkoski, A.E.; Hilpert, K.F.; Griel, A.E.; Etherton, T.D. Bioactive compounds in foods: Their role in the prevention of cardiovascular disease and cancer. Am J Med 2002, $113,71-88$.

Lima, A.R., Pereira, R.G.F.A., Abrahao, S.A., Duarte, S.M.D., Paula, F.B.D. (2010). Coffee bioactive compounds. In vitro antioxidant activity of green and roasted coffees before and after decaffeination. Quimica Nova, 33: 20-24.

Martin, K.R., Appel, C.L. (2010). Polyphenols as dietary supplements: a double-edged sword. Nutr Diet Suppl, 2: 1-12. 
Parada, J., Aguilera, J. M. (2007). Food microstructure affects the bioavailability of several nutrients. J Food Sci, 72: 21-32.

Parras, P., Martínez-Tomé, M., Jiménez, A. M., Murcia, M.A. (2007). Antioxidant capacity of coffees of several origins brewed following three different procedures. Food Chem, 102: 582-592.

Pekal, A., Drózdz, P., Biesaga, M., Pyrzynska, K. (2012). Screening of the antioxidant properties and polyphenol composition of aromatised green tea infusions. J Sci Food Agric, 92:2244-2249.

Perrone, D., Farah, A., Donangelo, C.M. (2012). Influence of coffee roasting on the incorporation of phenolic compounds into melanoidins and their relationship with antioxidant activity of the brew. J Agric Food Chem, 60:4265-4275.

Podsedek, A., Redzynia, M., Klewicka, E., Koziolkiewicz, M. (2014). Matrix effects on the stability and antioxidant activity of red cabbage anthocyanins under simulated gastrointestinal digestion. Biomed Res Int, 1-11.

ourshahidi, L.K., Navarini, L., Petracco, M., Strain, J.J. (2016). A comprehensive overview of the risks and benefits of coffee consumption. Compr Rev Food Sci Food Saf, 15:671-684.

Rossi, T., Gallo, C., Bassani, B, Canali, S., Albini, A., Bruno, A. (2014). Drink your prevention: beverages with cancer preventive phytochemicals. Pol Arch Med Wewn, 124(12): 713-722.

Ryan, L., Prescott. S.L. (2010). Stability of the antioxidant capacity of twenty-five commercially available fruit juices subjected to an in vitro digestion. Int J Food Sci Tech, 45, 1191-1197.

Sato, Y., Itagaki, S., Kurokawa, T., Ogura, J., Kobayashi M., Hirano, T., Sugawara, M., Iseki, K. (2011). In vitro and in vivo antioxidant properties of chlorogenic acid and caffeic acid. Int J Pharm, 403: $136-138$

Schenker, S., Heinemann, C., Huber, M., Pompizzi, R., Perren, R., Escher, R. (2002). Impact of roasting conditions on the formation of aroma compounds in coffee beans. J Food Sci, 67:60-66.
Se _czyk, Ł., S'wieca, M., Gawlik-Dziki, U. (2017). Soymilk enriched with green coffee phenolics Antioxidant and nutritional properties in the light of phenolics-food matrix interactions. Food Chem, 223: $1-7$.

Shimoda, H., Seki, E., Aitani, M. (2006). Inhibitory effect of green coffee bean extract on fat accumulation and body weight gain in mice. BMC Complement Altern Med, 6(9): 1-9.

Siebert, M., Berger, R. G., Nieter, A. (2018). Enzymatic mitigation of 5-O-chlorogenic acid for an improved digestibility of coffee. Food Chem, 258: 124-128.

Somporn, C., Kamtuo, A., Theerakulpisut, P., Siriamornpun, S. (2011). Effects of roasting degree on radical scavenging activity, phenolics and volatile compounds of Arabica coffee beans (Coffea arabica L. cv. Catimor). Int J Food Sci Tech, 46:2287-2296.

Spanos, G.A., Wrolstad, R.E. (1990). Influence of processing and storage on the phenolic composition of Thompson Seedless grape juice. $J$ Agric Food Chem, 38: 1565-1571.

Stefanello, N., Schmatz, R., Pereira, L.B., Rubin, M.A., da Rocha, J.B.T., Facco, G., Pereira, M.E., Mazzanti, C.M.A., Passamonti, S., Rodrigues, M.V., Carvalho, F.B., da Rosa M.M., Gutierres, J. M., Cardoso, A.M., Morsch V.M., Schetinger M.R.C. (2014). Effects of chlorogenic acid, caffeine, and coffee on behavioral and biochemical parameters of diabetic rats. Mol Cell Biochem, 388: 277-286.

S'wieca, M., Gawlik-Dziki, U., Dziki D., Baraniak B. (2017). Wheat bread enriched with green coffee- In vitro bioaccessibility and bioavailability of phenolics and antioxidant activity. Food Chem, 221: 1451-1457.

Şemen, S., Mercan, S., Yayla, M., Açıkkol, M. (2017). Elemental composition of green coffee and its contribution to dietary intake. Food Chem, 215: 92-100.

Vasudevaiah, A.M., Chaturvedi, A., Kulathooran, R., Dasappa, I. (2017). Effect of green coffee extract on rheological, physico-sensory and 
antioxidant properties of bread. J Food Sci Technol, 54(7): 1827-1836.

Tagliazucchi, D., Verzelloni, E., Bertolini, D., Conte, A. (2010). In vitro bio-accessibility and antioxidant activity of grape polyphenols. Food Chem, 120(2): 599-606.

Wei, F., Tanokura, M. (2015). Chemical changes in the components of coffee beans during roasting. In: Coffee in Health and Disease Prevention, Preedy, V.R. (ed.), Elsevier Inc: Academic Press, pp. 83-91.
Wootton-Beard, P., Moran, A., Ryan, L. (2011). Stability of the total antioxidant capacity and total polyphenol content of 23 commercially available vegetable juices before and after in vitro digestion measured by FRAP, DPPH, ABTS and FolinCiocalteu methods. Food Res Int, 44, 217-224.

Zhao, Y., Wang, J., Ballevre, O., Luo, H., Zhang, W. (2012). Antihypertensive effects and mechanisms of chlorogenic acids. Hypertension Res, 35(4): 370-374. 